\title{
Oral Allylestrenol: A Pregnancy-supporting Progestogen
}

\author{
${ }^{1}$ Narendra Malhotra, ${ }^{2}$ Ruchika Garg, ${ }^{3}$ Neharika Malhotra, ${ }^{4}$ Jaideep Malhotra
}

\begin{abstract}
Allylestrenol is a synthetic progestogen that has been in therapeutic use in the management of mild to severe cases of certain obstetric complications, like selected forms of miscarriage/abortion, threatened preterm labor, intrauterine growth restriction (IUGR), and gestational hypertension. Natural progesterone may be used for treatment; however, it has the property of being rapidly metabolized in the liver besides having little or no oral activity. While there are many other synthetic and orally administrable progesterone analogs in the market, most of them, which are 19-nortestosterone derivatives, possess various undesirable side effects like symptoms of intolerance and a tendency to virilization. Allylestrenol, despite being a 19-nortestosterone derivative, has no known side effects including those attributed to the other members of its class, which is theorized to be due to subtle differences in its chemical structure, giving it a unique mechanism of action consisting of a triple effect-trophoblastic, placentotropic, and $\beta_{2}$-adrenergic. The present review is mainly aimed at understanding the whys and wherefores behind the molecule's moderate efficacy and remarkable safety along with examining the data from various studies.
\end{abstract}

Keywords: Allylestrenol, Pregnancy, Progestogen.

How to cite this article: Malhotra N, Garg R, Malhotra N, Malhotra J. Oral Allylestrenol: A Pregnancy-supporting Progestogen. J South Asian Feder Obst Gynae 2017;9(4):297-303.

Source of support: Nil

Conflict of interest: None

Date of received: 10 October 2017

Date of acceptance: 1 December 2017

Date of publication: January 2018

\section{INTRODUCTION}

Progestogens can be classified as natural or synthetic. ${ }^{1,2}$ Natural compounds are those with chemical structures similar to those produced by living organisms. In contrast, synthetic progestogens (or progestins) are compounds generated in the laboratory whose structures have been modified and do not correspond to a naturally occurring steroid.

Progesterone plays a crucial role in the maintenance of pregnancy. Natural micronized progesterone is

\footnotetext{
${ }^{1,3,4}$ Consultant, ${ }^{2}$ Associate Professor

1,3,4Rainbow IVF, Agra, Uttar Pradesh, India

${ }^{2}$ Department of Obstetrics and Gynecology, Sarojini Naidu Medical College, Agra, Uttar Pradesh, India
}

Corresponding Author: Ruchika Garg, Associate Professor Department of Obstetrics and Gynecology, Sarojini Naidu Medical College, Agra, Uttar Pradesh, India, e-mail: ruchikagargagra@ gmail.com approved and available in India. ${ }^{3}$ Natural progesterone has mixed results when used in the first trimester in pregnant women with a history of recurrent miscarriage. Progesterone has been widely used to prevent threatened miscarriage, recurrent miscarriage, and preterm labor. In a Cochrane review, ${ }^{4}$ a meta-analysis performed on six randomized trials including singleton pregnancies with previous preterm birth, progesterone supplementation was associated with a significant reduction of delivery before 32 weeks and of perinatal mortality.

In a large meta-analysis ${ }^{5}$ consisting of 14 randomized, controlled trials $(2,158$ women selected regardless of gravidity and number of previous miscarriages), no statistically significant difference in the risk of miscarriage between progestogen and placebo or no treatment groups was observed. Results from a subsequent double-blind definitive trial [PROMISE trial, (Table 1)] conducted in women with a history of recurrent miscarriage, ${ }^{6}$ and given vaginal suppositories of micronized progesterone (432 women), progesterone showed no benefit in increasing the rate of live birth after 24 weeks of gestation. Norman et $\mathrm{al}^{7}$ conducted a large double-blind, randomized, placebo-controlled study [OPPTIMUM trial, (Table 1)] on pregnancy and infant outcomes in women at risk of preterm birth after being treated with vaginal progesterone taken daily from 22, 23, or 24 to 34 weeks of gestation. Progesterone was found to have no significant effect on the primary obstetric outcome or neonatal outcome or on the childhood outcome (taking cognitive score as index of measurement). Progesterone apparently had no longterm benefit or harm on outcomes in children at 2 years of age. Another on-going trial is the PRISM (Progesterone in Spontaneous Miscarriage) trial which is designed to evaluate the efficacy of vaginal progesterone in women presenting with vaginal bleeding in the first trimester. The result of this trial will provide evidence on the use of progesterone in threatened miscarriage.

The era of Evidence-based Medicine represents integration of clinical expertise, patient's values, and best available evidence in the process of decision-making related to patient's health care. The current available evidence is not in favor of the use of progesterone in recurrent miscarriage and for prevention of preterm birth.

Thus, there is a need to reexplore the progestogen molecule especially from synthetic origin which could provide an effective therapeutic approach in the management and prevention of such complications and also at 
Table 1: Summary of recent clinical trials on the effectiveness of vaginal progesterone therapy

\begin{tabular}{|c|c|c|c|c|c|}
\hline Author & Trial name & Disease setting & Number of patients, arms & Drug, dosage & Results \\
\hline $\begin{array}{l}\text { Coomarasamy } \\
\text { et } \mathrm{al}^{6}\end{array}$ & $\begin{array}{l}\text { PROMISE } \\
\text { (Progesterone } \\
\text { in Recurrent } \\
\text { Miscarriages) }\end{array}$ & $\begin{array}{l}\text { Women with } \\
\text { unexplained } \\
\text { recurrent } \\
\text { miscarriage }\end{array}$ & $\begin{array}{l}\mathrm{n}=836 ; \text { randomly } \\
\text { assigned to progesterone } \\
\text { ( } 404 \text { women) and } \\
\text { placebo ( } 432 \text { women) }\end{array}$ & $\begin{array}{l}400 \mathrm{mg} \text { micronized } \\
\text { progesterone } \\
\text { vaginal } \\
\text { suppositories BID }\end{array}$ & $\begin{array}{l}\text { No significantly higher } \\
\text { rate of live births with } \\
\text { progesterone therapy }\end{array}$ \\
\hline Norman et $\mathrm{al}^{7}$ & $\begin{array}{l}\text { OPPTIMUM (dOes } \\
\text { Progesterone } \\
\text { Prophylaxis To } \\
\text { prevent preterm } \\
\text { labour IMprove } \\
\text { oUtcoMe?) }\end{array}$ & $\begin{array}{l}\text { Women at risk } \\
\text { of preterm birth }\end{array}$ & $\begin{array}{l}n=1228 ; \text { randomly } \\
\text { assigned to progesterone } \\
(n=618) \text { and placebo } \\
(n=610)\end{array}$ & $\begin{array}{l}200 \mathrm{mg} \\
\text { progesterone } \\
\text { vaginal } \\
\text { suppositories OD }\end{array}$ & $\begin{array}{l}\text { Progesterone therapy } \\
\text { neither reduced risk of } \\
\text { preterm birth nor composite } \\
\text { neonatal adverse } \\
\text { outcomes, and had no } \\
\text { long-term benefit or harm } \\
\text { on outcomes in children at } \\
2 \text { years of age }\end{array}$ \\
\hline
\end{tabular}

the same time should be devoid of adverse effects. Hence, the present review highlights the detailed evaluation of allylestrenol, a promising molecule with its pharmacology, therapeutic uses, and clinical evidences.

Allylestrenol or allylestrenol or perselin $\left(\mathrm{C}_{21} \mathrm{H}_{32} \mathrm{O}\right)$ is a steroidal small molecule (average molecular weight: $300.48 \mathrm{gm} / \mathrm{mol}$ ) with progestational activity. ${ }^{8,9}$ It is widely marketed throughout Europe, including Russia and many European countries. ${ }^{9}$ Allylestrenol is also available in parts of Asia like Japan, Hong Kong, India, Bangladesh, Indonesia, and much of Southeast Asia, though notably not in the United States or Canada. ${ }^{9}$

Figure 1 shows allylestrenol is a synthetic progestogen structurally related to progesterone. Allylestrenol is synthesized from norethindrone by treating norethindrone with ethanedithiol and catalytic boron trifluoride. A thioketal is obtained which is reduced with sodium in liquid ammonia to result in the desired reductive elimination of the thioketal together with reduction of the 17-keto group. Oxidation of this alcohol with chromic acid in acetone followed by addition of allyl magnesium bromide gives allylestrenol. ${ }^{10}$

Earlier, natural progesterone has been used for treatment. However, it had a drawback of being rapidly metabolized in the liver into its biologically inactive pregnanediol metabolite besides having little or no oral activity. Currently, all the progestational agents in therapeutic use are synthetic steroids. Progestins have been

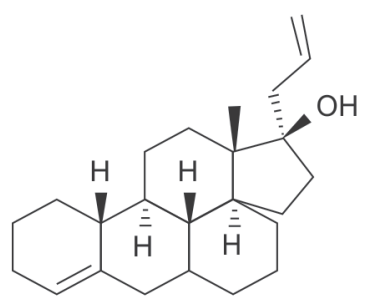

Allylestrenol

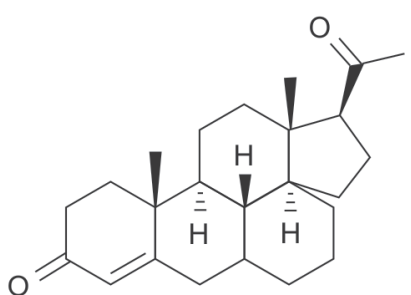

Progesterone
Fig. 1: Molecular structures of allylestrenol [(17 $\beta)$-17-(prop-2-en1 -yl)estr-4-en-17-ol] and natural progesterone (pregn-4-ene-3,20dione) recognized by their biological action, instead of their chemical structure. ${ }^{11}$

Today, several progestins have become available which are orally active. These have been products of 19-norandrostenolone and lie somewhere between natural androgens and estrogens. Although many progestins have displayed unusually strong progestogenic effects, various undesirable side effects have also been found, the two most important being symptoms of intolerance and a tendency to virilization. Also with several progestogens, prolonged administration for pregnancy maintenance has resulted in pseudohermaphroditism in the offspring. ${ }^{12}$

Allylestrenol, however, seems to be completely free from androgenic activity as well as well tolerated. ${ }^{12}$ This is in agreement with its lack of androgenic activity in animal studies as well. Allylestrenol in this respect, by not having any androgenic activity, has no teratological effects. Allylestrenol is also without estrogenic and glucocorticoid activity and treated as a pure oral progestogen. ${ }^{13}$

\section{MODE OF ACTION}

The mechanism of action of allylestrenol is multimodal and complex as shown in Flow Chart 1.

hCG, human chorionic gonadotropin; hPL, human placental lactogen; LAP, leucine amino peptidase; CAP, cysteine aminopeptidase.

\section{Trophoblastic Action}

The precursor cells of the human placenta-the trophoblasts-first appear 4 days after fertilization as the outer layer of cells of the blastocyst. The trophoblasts are critical for a successful pregnancy by mediating such critical steps as implantation, pregnancy hormone production, immune protection of the fetus, increase in maternal vascular blood flow into the placenta, and delivery. Allylestrenol stimulates the hormonal activity of the existing syncytiotrophoblast as the latter plays an important role in producing human chorionic gonadotropin (hCG), which in turn stimulates the production of progesterone. ${ }^{14}$ 
Flow Chart 1: Allylestrenol multimodal mechanism of action

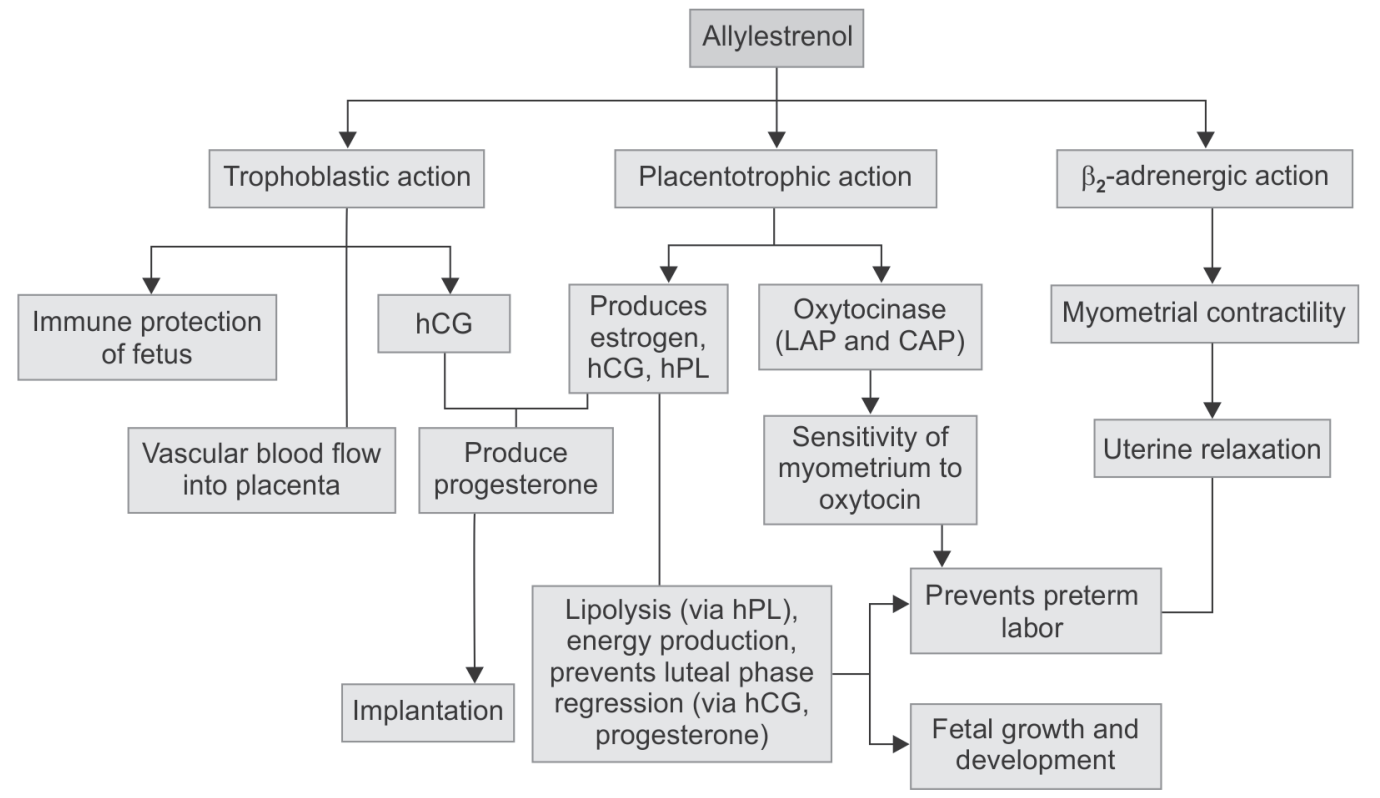

\section{Placentotrophic Action}

It was suggested that the pregnancy-maintaining effect of allylestrenol is at least partly due to a stimulation of the placental function. ${ }^{14}$ Progesterone is important to prevent preterm labor as it reduces the sensitivity of myometrium to oxytocin; ${ }^{15}$ and in humans, despite no decrease in placental progesterone production, activation of similar pathways preceding labor suggests the presence of an endogenous antiprogestin, whose secretion from the fetal adrenal rises markedly at the end of human gestation, ${ }^{16}$ pregnanediol, human placental lactogen (hPL, also called human chorionic somatomammotropin), serum heat stable alkaline phosphatase, serum leucine aminopeptidase, and oxytocinase.

\section{$B_{2}$-Adrenergic Action}

Stimulation of the $\beta_{2}$-adrenergic receptors has been found to inhibit uterine contractility. $\beta_{2}$-adrenergic receptors are present in the uterus, whereas the cardiac muscle appears to contain $\beta_{1}$-receptors. ${ }^{17,18}$
The relatively quick onset of allylestrenol clinical effect was explained that allylestrenol has some form of neural-mediated action resulting in uterine relaxation by stimulating the myometrial $\beta_{2}$-receptors. A combination of actions of allylestrenol-improvement of the trophoblastic function, which promotes the production of progesterone, and the $\beta_{2}$-adrenergic action-could account for the results of this drug in the treatment of myometrial spasmodic conditions that may interrupt pregnancy. ${ }^{14}$

\section{Absence of Androgenic Activity}

In the study by Bergink et al, ${ }^{13}$ binding of allylestrenol, its 3-keto metabolite and reference compounds for the androgen receptor in MCF-7 cells (human breast tumor cell line) and for human sex hormone-binding globulin (SHBG) (an important carrier protein for androgens) is analyzed. The results are tabulated in Table 2 .

At $4{ }^{\circ} \mathrm{C}$, the binding of 3-keto-allylestrenol to the androgen receptor was the same as that of medroxyprogesterone acetate and about 1.5 times stronger than

Table 2: Relative binding affinity of allylestrenol, its 3-keto metabolite and reference compounds for the androgen receptor in MCF-7 cells and human SHBG

\begin{tabular}{llll}
\hline & \multicolumn{2}{c}{ MCF-7 cells } & \\
\cline { 2 - 3 } Compound & Cytosol at $4^{\circ} \mathrm{C}$ & Intact cells at $37^{\circ} \mathrm{C}$ & Human SHBG at $37^{\circ} \mathrm{C}$ \\
\hline Testosterone & $32 \pm 4^{*}(8)^{\dagger}$ & $38 \pm 2(6)$ & $100 \%($ reference $)$ \\
$5 \alpha$-Dihydrotestosterone & $100 \%($ reference) & $100 \%$ (reference) & $446 \pm 79(5)$ \\
Allylestrenol & $2.8 \pm 0.2(3)$ & $<0.2$ & $0.9 \pm 0.2(3)$ \\
3-Keto-allylestrenol & $29 \pm 3(4)$ & $4.5 \pm 1(3)$ & $2.8 \pm 0.2(3)$ \\
Progesterone & $5.8 \pm 0.7(3)$ & $0.5(1)$ & $1(1)$ \\
Norethisterone & $17(1)$ & $7 \pm 0.7(8)$ & $10 \pm 0.8(4)$ \\
Medroxyprogesterone acetate & $29 \pm 2(3)$ & $8 \pm 1.1(5)$ & $1(1)$ \\
\hline
\end{tabular}

${ }^{*}$ Mean \pm standard error of mean; ${ }^{\dagger}$ Number of individual experiments 
that of norethisterone. At $37^{\circ} \mathrm{C}$ the binding affinity of 3-keto-allylestrenol was half that of norethisterone and medroxyprogesterone acetate. 3-Keto-allylestrenol, allylestrenol, and reference compounds which did not have androgenic activity (progesterone) displayed 7 to 12 times lower affinities for the androgen receptor in intact cells than in cytosol whereas compounds with androgenic activity (testosterone) displayed similar or slightly lower relative affinity for the androgen receptor in intact cells than in cytosol. The affinity of allylestrenol and its 3-keto metabolite for human SHBG was found to be very low. The natural androgens testosterone and $5 \alpha$-dihydrotestosterone binds very strongly to SHBG. Allylestrenol and its 3-keto metabolite bind weakly and this suggests that androgenic effects due to displacement of endogenous androgens from SHBG will not occur.

\section{MICRONIZATION}

Micronization of progesterone in particle sizes of $<10 \mu \mathrm{m}$ extensively increases the available surface area of the drug and enhances the aqueous dissolution rate and intestinal absorption of progesterone. Similarly, micronization of allylestrenol also helps in increasing the dissolution rate and oral bioavailability. Micronization is particularly useful for poorly water-soluble drugs. ${ }^{19}$ Allylestrenol, being a steroid and fat-soluble compound, micronization enhances its solubility in water and improves the clinical outcome.

\section{Therapeutic Uses and Clinical Evidences}

Allylestrenol has proven efficacy and safety in cases of threatened abortion, recurrent (habitual) abortion, threatened preterm labor, IUGR, or other complications related to progesterone deficiency. ${ }^{14,20}$ Allylestrenol has also been investigated for possible use in men for treatment of benign prostatic hyperplasia; however, it falls outside the scope of our present review.

\section{Miscarriage (Threatened and Recurrent Miscarriage)}

Allylestrenol allows for clinical treatment of threatened abortion as an oral tablet. ${ }^{14,20}$ Particularly, allylestrenol treatment during early detection results in a decrease in the number of miscarriages, ${ }^{14,20}$ probably due to stimulation of placental function (Table 3). ${ }^{21}$
Table 3: Success rate in controlling threatened abortion following treatment with allylestrenol in some of the studies of various authors

\begin{tabular}{llll}
\hline & $\begin{array}{l}\text { No. of patients } \\
\text { treated with } \\
\text { allylestrenol }\end{array}$ & $\begin{array}{l}\text { Positive } \\
\text { results }\end{array}$ & $\begin{array}{l}\text { Success } \\
\text { rate (\%) }\end{array}$ \\
Author & 36 & 33 & 92 \\
\hline Lambillon J & 99 & 69 & 70 \\
Borglin NE and Eliasson C & 27 & 24 & 89 \\
Gaudefroy M & 61 & 55 & 90 \\
Murphy MD and Gindhart & & & \\
FD* & 73 & 68 & 93 \\
Despodova C et al & 54 & 46 & 85 \\
Gyory G et al & 334 & 244 & 73 \\
Cortes-Prieto J et al & 85 & 74 & 87 \\
Sen Gupta S & 444 & 364 & 82 \\
Monasterolo F and & & & \\
Cassinelli L & & &
\end{tabular}

*The study published by Murphy MD and Gindhart FD in "The Journal of the Medical Society of New Jersey" was conducted in the USA

Being a time-tested agent for more than five decades, allylestrenol was also found to be safe and effective for use during pregnancy in women with selected cases of bad obstetric history (recurrent/habitual abortion).

Efficacy of allylestrenol combined with ritodrine (a tocolytic short-acting $\beta_{2}$-adrenoreceptor agonist) was observed in the treatment of habitual abortion in a much recent study by JinLan and Lan, ${ }^{22}$ in 144 patients divided into two equal groups (observation group, allylestrenol combined with ritodrine; control group, magnesium sulfate combined with allylestrenol). The results (Table 4) showed that efficacy of allylestrenol combined with ritodrine in the treatment of habitual abortion is significant, which can improve the rate of pregnancy with no obvious adverse reactions (Table 5).

\section{Intrauterine Growth Restriction/Fetal Growth Restriction/Small for Gestational Age}

According to one report ${ }^{23}$ more than 13.7 million infants are born every year at term with low birth weight (LBW), representing $11 \%$ of all newborns in developing countries. This rate is about six times greater than in developed countries. Almost $75 \%$ of all affected infants are born in Asia (mainly in South-Central Asia), 20\% in Africa, and about $5 \%$ in Latin America. The report established that many developing countries exceeded the internationally

Table 4: Allylestrenol plus ritodrine vs control $\left(\mathrm{MgSO}_{4}\right.$ plus allylestrenol) in the treatment of habitual abortion

\begin{tabular}{lll}
\hline & Observation group & Control group \\
\hline Total effective rate $(p<0.05)$ & $94.44 \%(68 / 72)$ & $63.89 \%(46 / 72)$ \\
Rate of pregnancy $(p<0.05)$ & $77.89 \%(56 / 72)$ & $55.56 \%(40 / 72)$ \\
Progesterone $(p<0.05)$ & $(190.12 \pm 60.97) \mathrm{mmol} / \mathrm{L}$ & $(163.21 \pm 64.88) \mathrm{mmol} / \mathrm{L}$ \\
hCG $(p<0.05)$ & $(7,319.98 \pm 1,032.03) \mathrm{U} / \mathrm{L}$ & $(5,797.01 \pm 954.12) \mathrm{U} / \mathrm{L}$ \\
Adverse reactions & $\mathrm{Nil}$ & $\mathrm{Nil}$ \\
\hline
\end{tabular}


Oral Allylestrenol: A Pregnancy-supporting Progestogen

Table 5: Success rate in controlling recurrent abortion following treatment with allylestrenol in some of the studies of various authors

\begin{tabular}{llll}
\hline & $\begin{array}{l}\text { No. of patients } \\
\text { treated with } \\
\text { allylestrenol }\end{array}$ & $\begin{array}{l}\text { Positive } \\
\text { results }\end{array}$ & $\begin{array}{l}\text { Success } \\
\text { (\%) }\end{array}$ \\
\hline Author & 6 & 4 & 67 \\
Borglin NE, 1960 & 25 & 19 & 76 \\
Borglin NE and Eliasson C & 81 & 71 & 88 \\
Sas M et al & 65 & 57 & 88 \\
Sen Gupta & 89 & 61 & 69 \\
Grio R et al & & & \\
\hline
\end{tabular}

recommended IUGR $(>20 \%)$ and LBW $(>15 \%)$ cut-off levels triggering public health action.

In Japan, Kaneoka et $\mathrm{al}^{21}$ prospectively studied the effect of allylestrenol treatment on 22 pregnancies with IUGR cases whose body weight $<10$ th percentile that of the overall obstetric population. Prenatal management consisted of bed rest, high protein diet, and oral administration of allylestrenol $30 \mathrm{mg} /$ day. The results were positive with estimated fetal weight of 1,431 $\pm 284 \mathrm{gm}$ at $33.8 \pm 2.1$ weeks' gestation increased to $2,612 \pm 451 \mathrm{gm}$ at $39.5 \pm 1.8$ weeks' gestation. Average weekly increase of body weight in these cases was significantly higher. Maternal plasma estriol value increased from $2.1 \pm 1.5$ to $4.1 \pm 3.6 \mathrm{mg} / \mathrm{mL}$, urinary estriol increased from $14.0 \pm 6.9$ to $23.7 \pm 11.2 \mathrm{mg} /$ day, and serum progesterone increased from $110 \pm 14$ to $133 \pm 31 \mathrm{ng} / \mathrm{mL} 2$ weeks after treatment. All increases of the hormone values were statistically significant. Therefore, the increases in maternal plasma hormone levels were at least partly due to stimulation of the placental function by allylestrenol.

Later, Kaneoka et $\mathrm{al}^{24}$ did a comparative study between 75 cases given no medication vs 75 cases given allylestrenol $30 \mathrm{mg}$ /day until delivery. The difference was statistically significant as the fetal weight averaged 1,242 $\mathrm{gm}$ at the initial measurement at an average 32.7 weeks gestation when the diagnosis of IUGR was made and 2,826 gm at the final measurement at 38.7 weeks in the treatment group, while it averaged $1,281 \mathrm{gm}$ at the initial gestation and 2,498 gm at the final measurement in the control group. Besides, the plasma estriol, urinary estriol, and plasma hPL rose significantly in allylestrenol group (Table 6).

\section{Threatened Preterm Labor}

Allylestrenol together with bed rest is an effective consideration in the control of threatened preterm labor with powerful pregnancy-maintaining and fetal weightpromoting actions, and a remarkable lack of androgenic activity. When used without tocolytics, recommended dosage of allylestrenol for the treatment of threatened preterm labor is 30 to $40 \mathrm{mg}$ / day (two $5 \mathrm{mg}$ tablets taken 3 to 4 times daily). ${ }^{25}$
Table 6: Success rate in controlling IUGR following treatment with allylestrenol in some of the studies of various authors

\begin{tabular}{llll}
\hline & \multirow{2}{*}{$\begin{array}{l}\text { No. of patients } \\
\text { treated with } \\
\text { allylestrenol }\end{array}$} & $\begin{array}{l}\text { Infant birth } \\
\text { weight }(\mathrm{gm})\end{array}$ & $\begin{array}{l}\text { Placental } \\
\text { weight }(\mathrm{gm})\end{array}$ \\
\hline $\begin{array}{l}\text { Kaneoka T } \\
\text { et al, 1982 }\end{array}$ & 22 & $212(\mathrm{p}<0.01)$ & Present \\
$\begin{array}{l}\text { Kaneoka T } \\
\text { et al, 1983 }\end{array}$ & 30 & $223(\mathrm{p}<0.01)$ & Present \\
$\begin{array}{l}\text { Singh J et al } \\
\text { Kaneoka T } \\
\text { et al, 1986 }\end{array}$ & 136 & Present & Not mentioned \\
\hline
\end{tabular}

In the study by Pandey et al, ${ }^{26} 75$ patients were admitted between 28 and 36 weeks of gestation with threatened preterm labor. Both primi- and multigravida were included. The study group consisted of 50 patients treated with $5 \mathrm{mg}$ allylestrenol two tablets 8 hourly and $20 \mathrm{mg}$ isoxsuprine 8 hourly, while the control group consisted of 25 patients treated with $20 \mathrm{mg}$ isoxsuprine alone 8 hourly. In the study group, $82 \%$ continued the pregnancy up to term compared with $65 \%$ in the control group; besides, $70 \%$ babies weighed $\geq 2,500 \mathrm{gm}$ in the study group compared with $60 \%$ in the control group. Therefore the combination of allylestrenol and isoxsuprine was superior to isoxsuprine alone. The study also showed that allylestrenol can be given with a tocolytic drug, as no adverse effects have been reported. The safety of allylestrenol both for the mother and the baby, despite prolonged use, has been reestablished and reconfirmed.

\section{Pregnancy-induced Hypertension}

Intrauterine growth retardation related to preeclamptic toxemia (PET) improved particularly well as shown by Kaneoka and Batra who compared their PET related cases to others. Incidental case histories and other data from numerous sources support the view that the PET symptomatology of the mother is also antagonized. If this is confirmed, it would fit well with what is known about the relationship between impaired placental flow and preeclampsia. ${ }^{24,27,28}$

\section{ADVERSE EFFECTS}

Safety studies suggest that allylestrenol usage at therapeutic dosage does not increase the rate of hypospadias in the fetus. ${ }^{29,30}$ Allylestrenol is therefore beneficial over other progestogens derived from 19-nortestosterone which, besides their progestational activity, also show some androgenic activity. Allylestrenol at therapeutic dosage does not increase the incidence of hypospadia in the fetus. 
Allylestrenol has no serious side effects. It has no known endocrinological side effects and thus, it is perfectly devoid of androgenic, estrogenic, and anabolic properties. $12,24,27,28,31-34$

\section{CONCLUSION}

Allylestrenol has an interesting pharmacological profile, combining potent pregnancy-maintaining and fetal weight-promoting properties, with a notable absence of androgenic activity. This probably explains the reason for the extensive use of allylestrenol during pregnancy in women with threatened abortion, selected cases of bad obstetric history (habitual abortion), threatened preterm labor, and IUGR for more than five decades. It exhibits a unique trophoblastic cum placentotropic action (stimulates the production of hormones and enzymes initially from syncytiotrophoblast followed by placenta) not yet been observed with any other progestogen, in addition to having a highly selective $\beta_{2}$-adrenergic action on the uterus.

Studies have confirmed that allylestrenol did not induce any anomalies or unwanted effects in both the pregnant women and children. No risk of inducing genital alterations, such as masculinizing effects of the female fetus, was observed in human embryos deliberately exposed to high-normal doses of allylestrenol given to the mother before undergoing legal termination of pregnancy. With strong pregnancy-maintaining and fetal weight-promoting properties, and a notable absence of androgenic activity, allylestrenol is an important consideration in the management of the obstetric complications as listed in our review.

\section{REFERENCES}

1. Schindler AE, Campagnoli C, Druckmann R, Huber J, Pasqualini JR, Schweppe KW, Thijssen JH. Classification and pharmacology of progestins. Maturitas 2003; Dec 10;46 (Suppl 1):S7-S16.

2. Romero R, Stanczyk FZ. Progesterone is not the same as $17 \alpha$-hydroxyprogesterone caproate: implications for obstetrical practice. Am J Obstet Gynecol 2013;208(6):421-426.

3. Progesterone brands in India. DrugsUpdate India. [cited 2017 Jul 26]. Available from: http:/ / www.drugsupdate.com/ brand/showavailablebrands/658/4

4. Rode L, Langhoff-Roos J, Andersson C, Dinesen J, Hammerum MS, Mohapeloa H, Tabor A. Systematic review of progesterone for the prevention of preterm birth in singleton pregnancies. Acta Obstet Gynecol Scand 2009;88(11): 1180-1189.

5. Haas DM, Ramsey PS. Progestogen for preventing miscarriage. Cochrane Database Syst Rev 2013 Oct;(10):CD003511.

6. Coomarasamy A, Williams H, Truchanowicz E, Seed PT, Small R, Quenby S, Gupta P, Dawood F, Koot YEM, Bender Atik $\mathrm{R}$, et al. A randomized trial of progesterone in women with recurrent miscarriages. N Engl J Med 2015 Nov;373(22): 2141-2148.

7. Norman JE, Marlow N, Messow CM, Shennan A, Bennett PR, Thornton S, Robson SC, McConnachie A, Petrou S, Sebire NJ, et al. Vaginal progesterone prophylaxis for preterm birth (the OPPTIMUM study): a multicentre, randomised, double-blind trial. Lancet 2016 May;387(10033):2106-2116.

8. Allylestrenol [Internet]. National Center for Biotechnology Information. Available from: https:/ / pubchem.ncbi.nlm.nih. gov/compound/allylestrenol\#section=Top.

9. Allylestrenol [Internet]. DrugBank (Bioinformatics/cheminformatics resource). Available from: https:/ / www.drugbank. ca/drugs/DB01431.

10. Winter MS, de Siegmann CM, Szpilfogel SA. 17-Alkylated 3-deoxo-19-nortestosterones. Chem Ind 1959;905.

11. Gunnet JW, Dixon LA. Hormones, sex hormones. In KirkOthmer encyclopedia of chemical technology; 2000.

12. Field-Richards S, Snaith L. Allylestrenol: a new oral progestogen. Lancet. 1961;277(7169):134-136.

13. Bergink EW, Loonen PB, Kloosterboer HJ. Receptor binding of allylestrenol, a progestogen of the 19-nortestosterone series without androgenic properties. J Steroid Biochem 1985 Aug;23(2):165-168.

14. Cortes-Prieto J, Oriol Bosch A, Arencibia-Rocha A. Allylestrenol: three years' experience with gestanon in threatened abortion and premature labor. Clin Ther 1980;20(5):200-208.

15. Khan-Dawood FS, Dawood MY. Estrogen and progesterone receptor and hormone levels in human myometrium and placenta in term pregnancy. Am J Obstet Gynecol 1984;150(5): 501-505.

16. Karalis K, Goodwin G, Majzoub JA. Cortisol blockade of progesterone. Obstet Gynecol Surv 1996;51(11):669-671.

17. Lands AM, Arnold A, McAuliff JP, Luduena FP, Brown TG Jr. Differentiation of receptor systems activated by sympathomimetic amines. Nature 1967 May;214(5088):597-598.

18. Editorial: Postponing premature labour. Br Med J 1977 Apr;1(6069):1118-1119.

19. Kawabata Y, Wada K, Nakatani M, Yamada S, Onoue S. Formulation design for poorly water-soluble drugs based on biopharmaceutics classification system: basic approaches and practical applications. Int J Pharm 2011;420(1):1-10.

20. Berle P, Budenz M, Michaelis J. Is hormonal therapy still justified in imminent abortion? Z Geburtshilfe Perinatol 1980;184:353-358.

21. Kaneoka T, Shimizu H, Matsuoka I, Taguchi S, Shirakawa K. Prenatal diagnosis and treatment of intrauterine growth retardation. Acta Obstet Gynecol Jpn 1982 Feb;34(2): 233-242.

22. JinLan Y, Lan Y. Efficacy observation of allylestrenol combined with ritodrine in treatment of habitual abortion. Eval Anal Drug-Use Hosp China 2015;15(12):1580-1582.

23. de Onis M, Blossner M, Villar J. Levels and patterns of intrauterine growth retardation in developing countries. [Internet]. Eur J Clin Nutr 1998 [cited 2017 Apr 14]. Available from: http://www.popline.org/node/274518.

24. Kaneoka T, Taguchi S, Shimizu H, Shirakawa K. Prenatal diagnosis and treatment of intrauterine growth retardation. Acta Obstet Gynecol Jpn 1986 Apr;38(4):561-569.

25. Basu SK, Gupta K. Allylestrenol in the management of threatened preterm labour. Obst Gynaecol Commun 1999; 1(4):1-3. 
26. Pandey LK, Gupta K, Purohit M. Allylestrenol in threatening symptoms before term. Obst Gynae Today 2004 Jun;9(6): 373-378.

27. Batra A, et al. Allylestrenol in the treatment of IUGR, a clinicpathological study. Poster presented April 8-11, 1986, Fourth AOCP, Tokyo, Japan.

28. Newsletter. 5th Asia-Oceania Congress of Perinatology held in Denpasar, Bali, July 7-9, 1988.

29. Mau G. Progestins during pregnancy and hypospadia. Teratology 1981 Dec;24(3):285-287.

30. Harlap S, Prywes T, Davies AM. Birth defects and oestrogens and progesterones in pregnancy. Lancet 1975;305(7908):682-683.
31. Madjerek Z, de Vissser J, van der Vies J, Overbeek GA. Allylestrenol, a pregnancy-maintaining oral gestagen. Acta Endocrinol 1960 Sep;35:8-19.

32. Borglin NE. Clinical evaluation of the progestational effect of allylestrenol. Acta Endocrinol 1960;51:929.

33. Wu DH. Gestational effect of allylestrenol (Gestanon). Endocrinol Jpn 1962;9(3):187-192.

34. Szontagh FE, Sas M, Traub A, Kovács L, Bárdóczy Á, Szereday $\mathrm{Z}$. The influence of different norsteroids on the hormone excretion and on the histomorphologic pattern in the trophoblast in early pregnancy. Gynaecologia 1963;156(6): 369-379. 